\title{
Managing Social Stability: The Perspective of a Local Government in China \\ Juan Wang
}

\begin{abstract}
Based on a town government's meeting memos between March 2001 and October 2007, annual work reports, and my interviews with local officials, I show that China's township governments have strived to contain, rather than resolve, social discontent. The tendency toward containment lies in two fundamental features of China's political institutions and central government strategy. First, in order to optimize the function of the petition system as a source of information without losing control, the Hu Jintao administration (2002-2012) passed regulations protecting the rights of petitioners on the one hand, and simultaneously put pressure on local officials to discourage petitioning, on the other. Second, the technical, institutional, and political features of China's cadre evaluation system encouraged local officials to take a short-term perspective on challenges, avoiding penalties rather than actually solving problems. KEYworDs: China, local government, social stability, petition system, cadre evaluation system
\end{abstract}

THE DYNAMICS OF CONTENTION AND THE IMPORTANCE OF INTERACTION between social movements and authorities have long been recognized (Tarrow 1994). On the one hand, there are studies about the formation, transformation, and evolution of both silent and disruptive contention (Kelliher 1992; Kerkvliet 2005; Scott 1985; Zhou 1996). On the other hand, works have shown the variety of social control mechanisms adopted by the state in the face of such movements (Boykoff 2007; Della Porta and Fillieule 2004; Goldstone and Tilly 2001), including sanction and censorship, arrest, and even torture (Earl 2006; Harff 2003; Ziegenhagen 1986), as well as "soft repression" such as ridicule, stigma, and silencing (Ferree 2004).

China scholars have applied the Western literature on contentious politics to the analysis of state-society conflict in contemporary 
China (especially the post- 1985 period) by examining the political opportunity, resource mobilization, and framing of China's contentious politics (Cai 2002; Chen 2004; Mertha 2008; Michelson 2007; Hurst and O'Brien 2002; Perry 2003; Thornton 2002; Yang 2005; Ying 2007; Yu 2003; Zhao 1998). In terms of the state's social control mechanisms, research has shown that there are three general state responses toward social resistance: concession, repression, and tolerance (Cai 2008b). The central and provincial levels of government tend to intervene in large-scale and more violent collective resistance (Cai 2008a). "Soft" repression such as using social ties to demobilize protesters has been used by local governments (Deng and O'Brien 2012).

China's township-level governments have ongoing interactions with the mass public and are thus on the front line of a broad range of contentious issues. Theorizing their social control mechanisms, therefore, requires an understanding of how local governments problematize social discontent, which demonstrates principal-agent relations as well as state-society relations.

In this article, I show that the primary goal of local governments in the 2000s was to contain social discontent, instead of resolving grievances, even though both were costly. The two political institutions that explain this outcome were China's administrative petition system and cadre evaluation system. Under the Hu Jintao administration (2002-2012), the central government relied on the administrative petitioning system as a source of information for local governments. In order to optimize the value of petitioning as a source of information without losing control, the Chinese central government initiated policies to officially protect the rights of petitioners while simultaneously putting pressure on local officials to discourage petitioning activities. The dilemma created by these policies was worsened by the cadre evaluation system that encouraged temporary responses to avoid penalties instead of finding solutions to the underlying problems over the longer run.

Theoretically, this article enriches the study of contentious politics in China by incorporating the principal-agent relationship into the study of state-society relations. As the front line of China's statesociety relations, the policing strategies of townships are also manifestations of the state's repressive capacity and the implementation of policies dictated by the central government. The case study method and process-tracing approach allow me to address the social control mechanisms employed by local governments from the perspective of local state agents, and to examine the causal sequence embedded in 
state agents' activities against local contexts. My analysis is based on the government's meeting memos in Yanglu ${ }^{1}$ town in central China between March 2001 and October 2007, as well as interviews with its leading officials and the town government's annual work reports. These sources permit a close analysis of how social issues emerged and were interpreted and managed over time. In addition, the language used in these memos provides perspectives "from within" that make intelligible the reasons state agents gave for their actions.

The article is organized as follows. In the first section I detail the practices of social control in Yanglu town in central China. I show that the town government pursued various strategies to contain, instead of resolve, social discontent. In the second section I account for this work style by looking at two primary causes. First, the inherent tension in the administrative petition system led to conflicting policy mandates from the central government: to both allow petitioning and control it. Second, the technical, institutional, and political features of China's cadre evaluation system promoted temporary responses to social problems in order to avoid penalties rather than to provide solutions to the problems raised by the petitioning process.

\section{The Repertoire of Social Control in Yanglu Town}

Social protests intensified in China in the late 1990s on a variety of issues, including taxation, corruption, seizure of land, and environmental issues. As they did, the Chinese government once again emphasized the importance of the petition system and local control. Following rising social protests in the late 1990s, the Sixteenth Party Congress in 2002 emphasized for the first time the importance of maintaining social stability (weiweng) under the new $\mathrm{Hu}$ Jintao administration. A series of reforms were initiated in the early 2000 s to create a "harmonious society" (hexie shehui). Tax reforms (mainly the tax-for-fee reform and elimination of agricultural taxes) were carried out between 2003 and 2006 to reduce the fiscal burden on peasants. Following what appeared to be accommodating gestures by the central government, there was a "high-tide" of petitioners gathering in Beijing in 2003 (Li, Liu, and O'Brien 2012). Investigating and intervening on the issues raised by petitioners strengthened the center's legitimacy, but it also encouraged more petitioners to go to Beijing. Unable to deal with the large number of petitioners, the central authorities soon turned toward restrictive measures in 2004 and demanded local authorities retrieve disruptive petitioners from their jurisdiction ( $\mathrm{Li}$, Liu, and O'Brien 2012). In addition, new petition 
regulations (2005) made township-level governments responsible for maintaining social stability within their jurisdictions. ${ }^{2}$ It was in this context that Yanglu town designed its practices of social control.

Yanglu is an ordinary town in terms of its population density and economic development. It has a resident population of 21,000 people; 1,800 hectares of farmland; and a total area of sixty-seven square kilometers. In 2006, a farmer's average income in Yanglu was 3,500 RMB, very close to the national average of 3,587 RMB. As a town with about eighty government employees ruling 21,000 residents, the town government lacked the coercive and fiscal capacity to resolve all the contentious issues of a mobile and increasingly active population. However, this did not prevent the town government from pursuing costly measures to contain, instead of resolve, social grievances. It did so by first categorizing social claims based on their likely effects on officials' career prospects, and then mobilizing personnel and fiscal resources to prevent petitioning that would have harmful effects on those career prospects.

\section{Problematizing Petitioning Activities and Setting Targets}

Similar to other local governments in China, Yanglu town government was confronted with a variety of complaints, communal disputes, and issues related to production safety. Petitioning was carried out by different social groups, such as army veterans, communitysponsored (minban) teachers, farmers, and retired cadres, who made claims relating to issues such as land compensation, mining conditions, village elections, environmental issues, delayed salaries, and pensions. From the perspective of Yanglu town government, however, the differences in actors and claims were of little importance compared to two particular types of incidents: claims made collectively (quntixing shangfang) and petitioning that reached higher levels of authority bypassing the town government, or "skip-level petitioning" (yueji shangfang). ${ }^{3}$

These two types of petitions were problematic due to their political implications for the career prospects of town officials. According to the 2005 petition regulations, collective petitions should not exceed five participants and petitions should appeal to the immediate administration within their jurisdiction. While these scale and procedural regulations of petitioning were targeted at petitioners, local governments that failed to ensure compliance to these standards would also be penalized. 
In order to prevent villagers from pursuing collective and skiplevel petitioning, the town government engaged in a series of measures, including mobilizing its staff, intimidating or persuading targeted villagers, and destroying registered case files.

\section{Mobilizing Staff: Material and Political Incentives}

In order to mobilize its human resources, Yanglu town government provided spiritual, financial, and political incentives and disincentives. Similar to other policies, the Yanglu town government designated personnel in the area and evaluated its employees on the issue of "stability control." Honors were given to those who had outstanding performance in this regard. Material incentives and political penalties were applied when social control required greater government effort.

Designating cadres from the town government to be responsible for each incident or potential social problem, the so-called lingdao baoan, was the main strategy implemented between 2001 and 2007 in Yanglu town. Yet the varying levels of emphasis on the social stability issue were reflected in the different rankings of the assigned officials, which ranged from leading figures in the town government to lower-level officials. Village-based township cadres (zhucun ganbu or baocun ganbu) were often regular township officials from a variety of governmental departments. These cadres did not necessarily live in villages, but in principle they were required to go to villages on a regular and frequent basis to manage, coordinate, and supervise village affairs. For these cadres, social stability control was often regarded as one of many responsibilities assigned to them, including fertility control, policy broadcasting, and returning farmland to the forest (tuigeng huanlin). ${ }^{4}$ After the issue of "petition and social stability" (xinfang wending) was explicitly listed as a standard in cadre performance evaluation in 2001 by the county government, Yanglu town government assigned village-based cadres to be in charge of this issue. ${ }^{5}$

Leading officials included key figures in four political institutions (lingdao banzi): the township Chinese Communist Party (CCP) committee, township government, local branch of the National People's Congress (NPC, the legislature), and the local branch of the Chinese People's Political Consultative Conference (CPPCC, an advisory body of government). These cadres ranked at the top of the power hierarchy at the township level and had the potential to be pro- 
moted to the county-level administration. Therefore, when these leading cadres instead of regular village-based ones were assigned to the work of social control, it was a clear indication of the rising importance of the issue in question. For example, after petitioners from another town within the county reached Beijing at the beginning of the Sixteenth National Congress of the CCP in November $2002,{ }^{6}$ the county government requested all towns to strengthen social control. As a result, key officials, as well as previous villagebased cadres, were made responsible for targeted petitioners. ${ }^{7}$

The work performance of designated cadres affected their career prospects. For example, a businessman from Yanglu sought redress in Beijing in July 2004, bypassing the town, county, prefecture, and provincial levels of government. The county government circulated a formal warning against Yanglu town government for its failure to maintain a "harmonious society." The town party secretary immediately submitted a written apology to the county government and demanded a deputy party secretary formulate reform plans by soliciting compulsory suggestions from each leading cadre. Subsequently, the party secretary announced that once collective and skip-level petitioning took place, those town cadres in charge of the work of social control would not be considered for promotion. ${ }^{8}$

In addition to political incentives, the town government also used material rewards and penalties. For example, the town government started in March 2007 to provide a monthly stipend of 60 RMB to encourage government staff working in petition control. ${ }^{9}$ This amount was close to a 5 percent salary increase in Yanglu. However, the penalties were equally severe. For example, following a campaign led by the county government in June 2006, Yanglu town government established a temporary leading team (lingdao xiaozu) headed by the party secretary to cope with persistent and abnormal petitioners. They identified three villagers that had been actively petitioning and complaining since 2005, including two "psychotic patients" and one "stubborn" petitioner. Five town cadres were assigned to monitor each of the three targets. ${ }^{10}$ The penalties were harsh should these cadres lose control of their targets. First, they would be suspended without pay. ${ }^{11}$ Second, responsible cadres would also be subject to fines ranging from $50 \mathrm{RMB}$ to $500 \mathrm{RMB}$, depending on the number of administrations being bypassed by the petitioners. Third, the assigned cadres were required to pay all the expenses (e.g., accommodation and transportation) incurred for retrieving vil- 
lagers from the places they traveled to, in addition to penalties decided by higher levels of authorities. ${ }^{12}$

\section{Propagating Policies and Monitoring Targets}

While mobilizing its staff helped control villagers, it was equally important for the town government to demobilize villagers and discourage them from pursuing collective or skip-level petitioning. Therefore, the Yanglu town government had attempted intimidation and persuasion by warning local residents about the severe consequences of "unlawful" petitions and by closely monitoring targeted villagers.

In order to "educate" the villagers and forewarn them of the consequences of their actions, Yanglu town government put up posters and distributed brochures to villagers, stressing the importance of the limited scale of appropriate (individual rather than group) complaints, and the formal procedure for lodging complaints and the importance of not skipping administrative levels. For example, following the national campaign, the town government announced the theme for 2002: "petition and social stability" (xinfang wending nian). The work of improving social knowledge on petition regulations was divided among different government bureaus. ${ }^{13}$ Slogans were painted on the walls around villages. Handouts were distributed to villagers. Propaganda vehicles with loudspeakers went into villages. ${ }^{14}$ Following the promulgation of the 2005 petition regulations, the township broadcast the new regulations for one month, and prepared at least eight posters and two propaganda vehicles. ${ }^{15}$

In addition to informing villagers selectively on some regulations on petitioning, Yanglu government kept track of villagers' activities, requesting designated cadres to report back with any potential problems. The frequency of mandatory reports varied, ranging from daily, biweekly, to monthly, and signaled the level of efforts from the town government on the issue of social control. For example, at the beginning of 2004, after the county government specified evaluation standards on the issue of social control, the Yanglu town party secretary requested a monthly report of village affairs from village-based cadres to the town party committee. ${ }^{16}$ Daily reports were usually used following specific requests or occurrence of the two particular types of petitioning. For example, there was a circular in November 2004 from the central government on "Preventing and Managing Disruptive Mass Incidents" (Yufang he chuli tufaxing qunzhong shijian wen- 
jian), and subsequent county government emphasis on preventing mass incidents (qunti shijian), safety accidents (anquan shijian), and criminal activities (xingshi shijian). Coincidentally, there were two cases of skip-level petitions from Yanglu town. In one case, a villager traveled to Beijing to appeal to a central government office. In another, eleven villagers from Yanglu lodged a collective petition to the county government bypassing the town government. In response, the town party secretary required daily updates on potential "social problems." 17 Similarly, after one villager from Yanglu managed to arrive in Beijing in October 2006 and planned to appeal to central government offices, the town government again demanded daily reports of villagers' whereabouts. ${ }^{18}$

A more intense surveillance measure would be taken during sensitive periods. These included annual meetings of the NPC and CPPCC, when senior officials were more likely to be reached by petitioners, or holidays when security personnel were off duty and the financial needs and concerns of villagers arose and consequently loan disputes and conflicts tended to intensify. ${ }^{19}$ During such occasions, the town government closely monitored all possible dissidents. For instance, in April 2005, the county government warned all town governments of the "Sunday Phenomenon" (xingqitian xianxiang), referring to petitioners' getting away on Sundays. ${ }^{20}$ Following the warning, the Yanglu town party secretary set up an emergency government headquarters with a twenty-four-hour on-call service, and a patrol team to watch potential trouble-making households and individuals. ${ }^{21}$ Similar measures were also taken during the National Day in October 2007 to guarantee immediate responses in case of "emergency" and to ensure a "trouble-free" holiday (meiren luan pao). ${ }^{22}$ The town government hired people to keep potential petitioners company wherever they went, and even stalled them by providing entertainment. For villages with persistent petitioners, the town government placed "intelligence" and secured informers. ${ }^{23}$ As the town party secretary stated, "As long as they do not go out and cause trouble, everything else would be okay." 24

Given the timing selected by petitioners, town government cadres often missed their vacations. As the town party secretary complained, "The more relaxed everybody else is, the more intense our work is" (bieren yue xian, women yue mang). ${ }^{25}$

Mobilizing government employees, propagating policies, and monitoring petitioners were aimed at the prevention of group complaints and skip-level petitioning, or to contain social discontent 
within local jurisdictions. As the Yanglu party secretary put it, "Small problems stay within villages, big problems stay within towns" (xiaoshi bu chu cun, dashi bu chu xiang). ${ }^{26}$

\section{Damage Control: Retrieving Petitioners and Destroying Case Files}

Despite careful management, some petitioners still succeeded in leaving the town with plans of reaching higher-level authorities or lodging collective petitions. Under these circumstances, Yanglu town government attempted to repair the political damage by retrieving these petitioners by all means necessary, and trying to cancel the records should petitioners have managed to hand their complaints to higher levels of government. Both bringing back petitioners and networking with senior officials were extremely costly for the town government.

Being ranked low on petition counts among peers carried serious weight in local officials' careers. Therefore, retrieving petitions became a widespread phenomenon in China. The people who rounded up and returned petitioners were known as retrievers (jiefang renyuan). Some retrievers were local officials, some were plainclothes police officers, and some were ruffians or private security companies hired by the local government. These retrievers staked out train stations, petition offices, and other government departments where petitioners may lodge complaints, and through intimidation or persuasion they deterred petitioners from pursuing their claims to higher authorities and forced them to return to their homes (Zen 2007). These activities of deterring petitioners were highly costly. As reported by Liaowang Weekly in November 2009, in addition to fees paid to private security companies that ranged between $200 \mathrm{RMB}$ and $500 \mathrm{RMB}$ per day, there were costs for lodging and transportation for those officials who traveled to Beijing to bring back petitioners. ${ }^{27}$ The number of assigned retrievers ranged from a few dozen to as many as 1,000 per province if it was during national meetings in Beijing, when petitioners had better chances to catch the attention of senior officials and have their grievances heard. In the May 2011 issue of Caijing Magazine, an article reported that the public security expenditures of local governments were 521.968 billion RMB. ${ }^{28}$

While Yanglu town's specific expenditures for retrieving petitioners could not be identified exactly, it followed the trajectories of other local governments. According to the town party secretary, the costs of transportation and lodging for retrievers together with penalties paid to the county government were as high as $10,000-20,000$ 
RMB per incident. ${ }^{29}$ As a county-level official stated, a "price has to be paid" (fuchu jingji daijia) for social stability and petition control. ${ }^{30}$ The price, however, was not paid to resolve social grievances but to contain them within local areas.

In addition to the costs of retrieving petitioners, there were hidden costs of networking to destroy petitioners' case files should they manage to reach government bureaus in Beijing. In other words, "zero filing" (ling dengji), instead of redressing social grievances, was the ultimate goal of petition control by the town government. For example, following failed containment in examples mentioned above (i.e., the villager from Yanglu town who appealed to central offices in Beijing in November 2004, and the eleven villagers who lodged a collective petition to the county government, bypassing the town government), the town government enhanced its social control by highlighting the importance of zero filing of petitioner's cases with higher-level authorities. ${ }^{31}$ Their superior at the county level explicitly shared the aim and assisted in reaching the ultimate goal of social control. ${ }^{32}$

\section{Explaining the Pattern of Social Control in Yanglu}

As shown above, the Yanglu town government pursued various measures and mobilized personnel and material resources to contain, rather than resolve, social discontent. Their ultimate goal on the issue of social stability was to prevent social actors from filing their cases with higher-level authorities. Why did Yanglu town engage in such costly activities for containing social grievances? In this section I will show that the rationale lies in fundamental problems inherent in two political institutions: the petition system itself and the cadre evaluation system.

\section{Administrative Petitioning as a Source of Information}

Secrecy is a crucial feature of authoritarian rule. In order to overcome information paucity and unreliability, autocrats rely on a variety of channels (Barros 2011; Schedler and Hoffmann 2012; Svolik 2012), from elections to secret police. China's post-1949 petition system (xinfang) is similar to that of the Soviet Union (Hough 1969) and East Germany (Rueschemeyer 1991), which designated personnel and offices to receive and respond to social requests. Whereas the administrative petitioning system helps the central authorities to obtain information about society and its local agents, relying on peti- 
tioning as a source of information has two problems. First, information provided by petitioners may not be accurate. Second, allowing too much petitioning can embolden social actors and ultimately endanger regime stability. Therefore, the optimal value of petitioning as a source of information is to maximize its function without losing control. As such, China's central government under the Hu administration attempted to regulate petitioning activities, officially protecting the rights of petitioners, and simultaneously put pressure on local officials to discourage petitioning activities.

The first set of regulations on petitioning (xinfang tiaoli) was issued by the State Council in October $1995 .{ }^{33}$ The primary unit made accountable for receiving petitions and solving social grievances was each administrative level above the county, assisted by different departments corresponding to specific grievances (fenji fuze, guikou guanli). The 2005 petition regulations made important changes to protect the rights of petitioners and reinforce the information-collection function of xinfang bureaus (Minzner 2006), and they improved the obscure distribution of responsibilities between local governments (kuai) and functional administrations (tiao) (Zhao 2007).

While intervening and investigating issues raised by petitioners strengthened the center's legitimacy, it also encouraged more petitioners to go to Beijing. Starting from 2004, therefore, the central authorities turned toward more restrictive measures. The Central Joint Committee began to rank all provinces monthly on "petition counts" according to the number of registered disruptive appeals at the "Majialou Distribution Center," where trouble-making petitioners were caught and sent back to their place of origin $(\mathrm{Li}, \mathrm{Liu}$, and O'Brien 2012). Following the lead of the committee, provincial and prefectural levels of government also encouraged competition by ranking "petition counts" of their immediate subordinate levels of government. Between 2007 and 2009, the CCP Central Committee, the General Office of the State Council, the Central Commission for Discipline Inspection of the CCP Central Committee, and the Ministry of Supervision issued a number of notices to highlight the political importance of petition-handling work and to specify administrative penalties for party members and civil servants who violated petition regulations. ${ }^{34}$

Central mandates were delivered formally to Yanglu town government based on two indicators: the number of meetings with social control as one theme to be discussed (see Table 1) and the devoted 
Table 1 Social Control as a Theme in Town Meeting Memos

\begin{tabular}{lccc}
\hline Year & $\begin{array}{c}\text { Total Number } \\
\text { of Recorded } \\
\text { Meetings }\end{array}$ & $\begin{array}{c}\text { Number of Meetings } \\
\text { with a Thematic Focus } \\
\text { on Social Control }\end{array}$ & Percentage \\
\hline Mar.-Dec. 2001 & 24 & 8 & 33 \\
2002 & 38 & 14 & 37 \\
2003 & 34 & 10 & 29 \\
2004 & 28 & 18 & 64 \\
2005 & 29 & 17 & 59 \\
2006 & 20 & 10 & 50 \\
Jan.-Oct. 2007 & 33 & 20 & 61 \\
\hline
\end{tabular}

Source: Data collected and compiled by author.

coverage on the issue of social stability in the town government's annual work reports. Table 1 illustrates that the importance of social control rose over the years, from being addressed in 33 percent of all meetings in 2001 to 61 percent in 2007 , with a steep increase in 2004.

Another measure of the increasing significance of social control for the town government can be found in its annual work reports. Compared to one sentence devoted to the issue of "social stability" in 2002 and 2003, a whole section appeared in the government reports of 2005 and $2006 .{ }^{35}$ In addition, according to the government report, Yanglu town invested 20,000 RMB in 2005 to build a meeting hall as a service point in the name of "strengthening public order" (zonghe zhili). This service point was to gather all relevant government bureaus and parties (such as the office of letters and visits, court, and the bureau of land) to work collaboratively and respond to petitioners' complaints more efficiently. ${ }^{36}$

Even though Yanglu town government formally demonstrated its compliance with policy mandates, what worsened the dilemma local officials faced was the preference of Chinese people using administrative petitioning over formal litigation. According to the national xinfang bureau, petitions to the party and government xinfang offices at the county level and higher totaled 137.3 million in 2004 and 126.56 million in 2005. ${ }^{37}$ The Supreme People's Court reported in 2003 that China's judiciary handled 42 million letters and visits between 1997 and 2002, as opposed to 30 million formal legal cases (Minzner 2006). Reasons behind such social reliance on administrative petitioning included its effectiveness ( $\mathrm{Gu} 2002$; O'Brien and $\mathrm{Li}$ 
2004), the path dependence of China's historical petition system, a cultural tendency of reliance on administrative channels (Minzner 2006), as well as cultural preference for less confrontational means of dispute resolution (Zhang 2009).

In the post-2000 period when the $\mathrm{Hu}$ administration highlighted the building of a "harmonious society," social actors were motivated to lodge petitions for a variety of reasons. First, resistance achieved extra leverage over local officials by applying multiple constraints or seeking favorable intervention from above through personal connections (Cai 2010). Second, "rightful resistance" where local residents claimed their rights based on discrepancies between central policy mandates and local government malfeasance continued (O'Brien and Li 2006). Third, new strategic and opportunistic petitioning to protect or advance one's interests without reference to local malfeasance emerged (Chen 2012; Tian 2010).

Strategic social actors had noted the importance of bypassing the prescribed procedure for petitions (O'Brien and Li 1995), not necessarily because higher levels of government were more effective in responding but because such activity pressured lower levels of government to pay attention and reach possible compromises. In one of the examples mentioned above, when petitioners from the county reached Beijing during the Sixteenth Party Congress in November 2002, the Yanglu town party secretary announced in a meeting that, during this sensitive period of time, the town government could compromise on certain issues or make promises to calm down petitioners. ${ }^{38}$

When officials' fear of collective petitioning was made public, unreasonable demands were also brought up to local governments. In 2006, for example, following the central policy of abolishing agricultural taxes and fees from peasants, some farmers started refusing to pay legitimate land-contracting fees. ${ }^{39}$ The town party secretary complained that rural residents had recognized that petitioning to higher authorities was the "weakness" (ruodian) of local governments and taken advantage of it: "Petitioners come to us for everything. Some are reasonable. Some are just plain crazy. They know that we have to deal with them. We cannot let them appeal to higher authorities, no matter how crazy their claims are." 40

Compromises made by local governments further encouraged rural residents to pursue solutions to their problems from administrative bodies instead of legal channels. In early 2006, for example, two children in Yanglu drowned while swimming in a village river. Their 
parents went to the town party secretary, requesting compensation from a company operated upstream. They argued that the wastewater from the company increased the water level, which led to the accident. The company, on the other hand, insisted that they clearly warned about the danger of swimming in the river by putting up a sign on the bank. Without getting compensation directly from the factory, the parents, together with their family members and relatives, gathered in front of the town government office demanding justice. They placed the bodies of the children in front of the government office, pressuring town cadres to solve the issue as soon as possible. Concerned about the "negative impact" (fumian yingxiang) on the image of the town government and disapproval from the county government, the town government ended up negotiating with the factory and paying compensation together to settle the case. ${ }^{41}$

There was increasing political awareness from social actors about the township governments' fragility. The town government was penalized by the mere occurrence of demands from social actors, whether reasonable or unreasonable, being brought to higher levels of government through collective or skip-level petitioning. Under such circumstances, petitioners frustrated China's local governments, including Yanglu town. In September 2003, for example, the importance of petition control escalated right before the National Day. Emphasizing the importance of containing petitioners, the deputy party secretary of the province where Yanglu is located stated that to control petitioners was as important as controlling SARS (severe acute respiratory syndrome), a disease that broke out in China in 2002 and 2003 that caused hundreds of death. ${ }^{42}$

The conflicting policies made by the central authorities and the reliance of Chinese citizens on administrative petitioning had placed local state agents in a difficult position. The dilemma faced by local governments to implement policies while confronting an active society was worsened by the politics of a cadre evaluation system that encouraged temporary responses toward policy mandates instead of optimal results.

\section{Cadre Performance Evaluation System}

China's current cadre evaluation system that seeks to align the interests of local agents is primarily based on the Provisional Regulations of the State Public Servant promulgated in 1993, as well as a number of subsidiary regulations issued by the Ministry of Personnel including selection, appointment and promotion, resignation and dismissal, 
rotation and exchange, internal competition, and performance evaluation (Lam and Chan 1996; Tong, Straussman, and Broadnax 1999). Existing work has largely focused on the evaluation of public service reform for personnel control (Bai and Zi 2000; Burns 2007; Chou 2004). Indeed, the institution of assessing government and cadres' work (kaohe) has shaped the behavior of state agents (Nathan 2003), but what deserves further investigation is the way in which and the extent to which the institution constrains or enables agent behavior.

The cadre performance evaluation and promotion system sends signals of the policy orientation of higher-level authorities and creates incentives for lower-level state agents to follow orders. This section highlights three interrelated features of the performance evaluation system. First, technically, it is virtually impossible to fulfill the multiple and sometimes conflicting tasks assigned by the center, and to meet the different and ever changing priorities and work targets. Second, the institution of cadre evaluation as a ranking system involving competition with peers suggests the importance of coordinating with superiors for a better result. Third, the built-in discretion in the cadre evaluation system allows influence from principals in the final ranking of their clients. These three features suggest why only few are motivated toward optimal performance with respect to underlying policy issues; the majority of local state agents are more sensitive to the disincentives and thus seek to avoid penalties in order to remain in office and enjoy existing privileges.

The technical complexity and uncertainty of the work performance assessment system lie in the multiple and sometimes conflicting tasks assigned and the varying priorities of work targets. Between March 2001 and October 2007, for example, 80 percent of government meetings in Yanglu were to circulate documents, briefings, and tasks of upper levels of authorities, with issues ranging from rectification of work style, vegetable planting, family planning, investment attraction, immigrant workers, infrastructure construction, and petition controls.$^{43}$ Important issues stressed by upper levels of authorities changed over the years from returning farmland to forest (tuigeng huanlin) in 2002, encouragement of labor immigration in 2003 and 2004, petition control in 2005 and 2006, to New Socialist Countryside Construction (shehui zhuyi xinnongcun jianshe) in 2007. In addition, there were some constant targets set every year, such as fiscal revenue, but its weight vis-à-vis other targets varied every year as well. Furthermore, due to random and frequent political campaigns initiated by the central, provincial, and even city and county 
levels of government, township-level governments faced an inconsistent evaluation system. In response, local governments have selectively implemented central policies (O'Brien and Li 1999; Bernstein and Lü 2003; Edin 2003).

What made the issue of social stability particularly difficult for the town government was that township-level government sometimes had neither the administrative authority nor the capability to redress many of the claims raised by villagers. For example, many legal issues reported by farmers to the town governments were beyond their jurisdictions, or required the coordination of multiple departments, surpassing the scope of the town government's authority. However, because townships were the lowest official level of government in China and above the grassroots cadres in the villages who may easily shirk their responsibilities, townships had no choice but to deal with these problems. As the Yanglu town party secretary put it, "The county and prefecture governments would penalize us first once they see any incidents of collective or skip-level petitioning, without asking why they took place (buwen qinghong zaobai)." ${ }^{44}$

Second, performance evaluation is a ranking system with competition involved. The outcome does not have to be optimal, only better than that of peers. Therefore, the town government frequently compared itself with its fellow townships and coordinated with county authorities so as to clarify its standing vis-à-vis others and to identify a satisficing outcome. For instance, in April 2001, the beginning of a lunar calendar year, the head of the town government evaluated Yanglu based upon the overall situation of the county before specifying annual tasks. ${ }^{45}$ Again in the middle of the year, trying to encourage officials to seek solutions to fiscal deficits and generate selfreliance, the head of the town government stated that "[our] fiscal [situation] is difficult. We all need to take responsibility and look for solutions. The whole county's situation is not promising, except for two other towns. We all need to increase revenue and reduce expenditure." ${ }^{\prime 46}$ At the end of the year, the township coordinated with a variety of county departments to probe the implicit targets set for Yanglu.

Third, the final evaluation result is partly at the discretion of superiors. In fact, despite a series of reforms in China's cadre evaluation system, manipulation of appointment and promotion was a common practice (Sun 2008). Even though research has repeatedly demonstrated the correlation between economic performance (in the form of tax extraction) and cadres' career trajectories at the local 
level (Landry, Lü, and Duan 2013; Oi 1999), the discretion in the formal procedure of nominating, scrutinizing, and deliberating candidates and finalists may simply endogenize preexisting networks and competition. The problem that the cadre evaluation system only partially motivates officials applies not only to central elites (Shih, Adolph, and Liu 2012), but also to local state agents. In fact, a survey of 571 township, county, and prefectural levels of party and government leaders in 2003 and 2004 from a province in central China, for example, revealed that 75 percent of these officials regarded building networks with superiors (la guanxi, pao guan) as the dominant norm in officialdom, and 55 percent emphasized the operation of nepotism and faction politics (Xiao 2005).

Whereas career advancement was not necessarily a result of superior work performance, disincentives of demotion or material penalties were indeed applied in response to petitioning in the 2000s, particularly given the difficulties of covering up evidence of collective and skip-level appeals. For example, two county party secretaries in Guizhou were demoted for failing to prevent petitioners from going to Beijing ( $\mathrm{Li}, \mathrm{Liu}$, and O'Brien 2012, footnote 48). Similarly, the head of a town government in Sichuan province was dismissed and the town party secretary given disciplinary warning within the party (dangnei jinggao chufen) when a farmer in Anxia County in Sichuan went to Beijing. ${ }^{47}$

The same disincentives were applied in Yanglu town government. When one villager who persistently petitioned to Beijing managed yet again to arrive in the capital city in October 2006, the head of the village was given a record of demerits (xingzheng jiguo) and dismissed from all his positions within the party (chexiao dangnei yiqie zhiwu). All assigned village-based town officials were fined $100 \mathrm{RMB}$ and disqualified as candidates for the town government's annual rewards for outstanding government employees. ${ }^{48}$

Given the technical difficulties of assignments, the institutional design of competition, and the politics of the cadre evaluation system that made penalties more certain than rewards, the primary motivation behind practices of the town government has been seeking temporary solutions to identified problems. Two indicators provide evidence for this finding. First, state agents problematize reality based on its potential negative impact on their career prospects. Second, state agents strive to limit the negative impact rather than endeavor to tackle issues at the source. As we have seen, Yanglu town governments problematized group complaints and skip-level 
petitioning, occurrence of which they should avoid, and resorted to preventing the escalation of conflict instead of seeking to solve social grievances.

\section{Conclusion}

Based on a detailed case study of Yanglu town government's strategies of managing the work of social stability, I illustrate how and why China's local governments in the 2000s have endeavored to contain, rather than resolve, social discontent. The repertoire of social control mechanisms demonstrated in Yanglu town differed in important ways from the interference by governments at provincial and national levels that were conditioned on the scale and level of disruption documented by existing scholarship.

The origin of the rationale for Yanglu town government, I argue, lies in fundamental issues inherent in two political institutions. First, in order to optimize the function of the petition system as a source of information without losing control, the central government passed regulations protecting the rights of petitioners but simultaneously put pressure on local officials to discourage petitioning. The second reason for local governments in containing rather than redressing social grievances were disincentives provided by China's cadre evaluation system. Complex and ever changing missions assigned by superiors nurtured superficial responses. Competition embedded in the evaluation system motivated emphasis on coordination with superiors rather than addressing social and policy problems. The disbelief in performance-based career advancement further discouraged effort toward optimal work results. While promotion was uncertain, political and material penalties were real and harsh in the particular area of petitioning, despite difficulties for the town government to redress social grievances. Therefore, China's local governments, such as Yanglu town, resorted to preventing the escalation of conflict, instead of seeking to solve social grievances.

I do not deny that local agents' choices are sometimes results of incremental bureaucratic decisionmaking or a function of limited responsive capacity of local governments. Given the complex and varying mandates, Yanglu town cadres did attempt to muddle through to fulfill satisficing goals. However, what differentiated their behavior in petition control from bureaucratic routine were the high costs incurred and great efforts they made in managing social stability. In addition, some social grievances were indeed difficult to resolve 
within the administrative jurisdiction of Yanglu town, which led to a temporary solution of containment when local officials were pressured by the cadre evaluation system. However, the real vulnerability of local state agents lay not in their limited responsive capacity but in the revelation of their concern to social actors, which increased the leverage of social actors vis-à-vis the local state and encouraged group and skip-level petitioning. Therefore, it was the politics of central-local relations and state-society relations, rather than bureaucratic incrementalism or administrative restriction, that determined the choices of local state agents.

This case study of the rationale and mechanisms of social control in Yanglu has important implications for the study of contentious politics in authoritarian regimes and in China in particular. In order to control the masses, authoritarian regimes combine coercion and "soft repression" when they are confronted with social resistance. In addition to such reactive measures, authoritarian regimes make efforts to manage and deter underlying problems before they arise. The effectiveness of such mechanisms requires compliant agents to undertake these tasks and that they have unbiased information about society. However, the organization of authoritarian regimes may result in deceitful agents and unreliable information, which then hamper the responsive capacity of the state. In the case of China, the petition system is an important source of information for the CCP regime. However, the interests of local agents resulted from the politics of the cadre evaluation system and competition in low petition counts, which drove them not to solve or redress grievances but to contain social discontent and cover up evidence of its expression. In other words, local state agents actively engaged in misleading the central government. At the same time, an important information channel for the regime to identify, diffuse, and cope with discontent was effectively undermined. This tendency may ultimately endanger the responsive and repressive capacity of the regime toward social grievances.

Juan Wang is assistant professor of political science at McGill University.

\section{Notes}

An earlier version of this study was presented at the 2009 meeting of the American Political Science Association, and at the Preserving Stability in China Conference held by the University of Technology in Sydney in July 
2011. I would like to thank Andrew Mertha, Rachel E. Stern, and two anonymous reviewers for their helpful comments. I am indebted to Stephan Haggard for his constructive suggestions that greatly improved the theoretical perspective and presentation of this article.

1. To protect the confidentiality of our interviewees, we use a pseudonym for the name of the township.

2. The 2005 amended petition regulations are available in Chinese online at www.gjxfj.gov.cn/2005-01/18/content_3583093.htm (accessed February 11, 2011).

3. Record $\# 07242002$. In this article I code government memos in Yanglu town as records.

4. Record \#H-2000-2003.

5. Record \#04112001.

6. The Sixteenth Party Congress was held in Beijing between November 8 and November 14, 2002. The county meeting was gathered on November 12 .

7. Record \#11122002.

8. Record \#07172004.

9. Record \#03142007.

10. Record \#H-20060606-2.

11. Record \#H-200604282100-4.

12. Record \#H-20060606-3.

13. Record \#2242002.

14. Record \#3192002.

15. Record \#04272005.

16. Record \#02092004.

17. Record \#11192004.

18. Record \#11042006.

19. Records \#12082004, \#111212005.

20. Record \#04122005.

21. Record \#04122005.

22. Record \#200710141530-1.

23. Record \#200710141530-3.

24. Interview with town party secretary in Yanglu on October 27, 2007.

25. Ibid.

26. Record \#03092004.

27. Xinhua news, November 24, 2009, http://news.xinhuanet.com /politics/2009-11/24/content_12531833.htm (accessed August 29, 2013).

28. Xu Kai et al., "Pūblic Security Bill" (gonggong anquan zhangdan), Caijing Magazine, May 8, 2011, http://magazine.caijing.com.cn/2011 -05-08/110712639.html (accessed August 29, 2013).

29. Interview with town party secretary in Yanglu on October 7, 2007. See also Yu Jianrong's speech online, http://news.ifeng.com/opinion/meiti $/ \mathrm{ph} / 200807 / 0728$ 1901_679010.shtml (accessed October 20, 2012).

30. Record \#0930-2003.

31. Record \#12212004. 
32. Record \#04122005.

33. The 1995 petition regulations are available online at http://wenku .baidu.com/view/a01d134569eae009581 bec11.html (accessed August 28, 2014).

34. Such as the CCP Central Committee and the State Council's "Opinions on Further Strengthening Petition Work in the New Stage" in March 2007; the Central Commission for Discipline Inspection of the CCP Central Committee's "Opinions on Penalties of Party Members in Violating Petition Regulations" in July 2008; the Ministry of Supervision, the Ministry of Human Resources and Social Protection, and the Bureau of Letters and Calls' "Regulations Regarding Penalties of Civil Servants in Violating Petition Regulations (Draft)" in June 2008; in 2009 the General Office of the CCP Central Committee and the General Office of the State Council issued three new documents: "Opinions on the Regular Reception by Leading Officials of Citizens Who Come to Make Complaints," "Opinions on the Regular Organization of Officials from Central Departments of the Party and Government to Visit Grassroots Localities," and "Opinions on the Systematization of the Efforts to Sort Out, Check and Resolve Conflicts and Disputes." For the opinion in 2007, see www.pcedu.gov.cn/News_view.asp ?ID=4783; for the notice in 2008, see www.gov.cn/jrzg/2008-07/24/content 1054991.htm (accessed on February 11, 2011).

35. Yanglu Town Government Annual Work Reports (2002, 2003, 2005, 2006, missing year 2004).

36. Yanglu Town Government Annual Work Report (2005).

37. People's Daily, April 29, 2006, www.china.com.cn/chinese/PI-c /1197687.htm (accessed July 4, 2014).

38. Record \#11122002.

39. Interview with town party secretary in Yanglu on October 27, 2007.

40. Ibid.

41. Ibid.

42. For more information about SARS, see reports and updates at the World Health Organization online, www.who.int/csr/sars/archive/en/ (accessed March 3, 2014). 2006).

43. Yanglu Town Government Annual Work Reports (2002, 2003, 2005,

44. Interview with town party secretary in Yanglu on October 27, 2007.

45. Record \#04302001.

46. Record \#05082001.

47. Interview with town party secretary in Yanglu on October 27, 2007.

48. Record \#10082006.

\section{References}

Bai, Mu, and Yin Zi. 2000. "Toushi Zhongguo Gongwuyuan" [A close examination of Chinese civil servants]. Zhongguo Gongwuyuan [Chinese public servant] 11: 11-14. 
Barros, Robert. 2011. "On the Outside Looking In: Secrecy and the Study of Authoritarian Regimes." www.udesa.edu.ar/files/UAHumanidades /eventos/PaperBarros31111.pdf.

Bernstein, Thomas, and Xiaobo Lü. 2003. Taxation Without Representation in Contemporary Rural China. Cambridge: Cambridge University Press.

Boykoff, Jules. 2007. "Limiting Dissent: The Mechanisms of State Repression in the USA." Social Movement Studies 6: 282-310.

Burns, John P. 2007. "Civil Service Reform in China." OECD Journal on Budgeting 7: 1025.

Cai, Yongshun. 2002. "The Resistance of Chinese Laid-Off Workers in the Reform Period." The China Quarterly 170: 327-344.

- 2008a. "Disruptive Collective Action in the Reform Era." In Popular Protest in China, ed. K. O'Brien, 163-178. Cambridge: Harvard University Press.

- 2008b. "Power Structure and Regime Resilience: Contentious Politics in China." British Journal of Political Science 38: 411-432.

- 2010. Collective Resistance in China: Why Popular Protests Succeed or Fail. Stanford: Stanford University Press.

Chen, Xi. 2004. "Art of Troublemaking: Chinese Petitioners' Tactics and Their Efficacy." Manuscript.

. 2012. Social Protest and Contentious Authoritarianism in China. New York: Cambridge University Press.

Chou, Bill K. P. 2004. "Civil Service Reform in China, 1993-2001: A Case of Implementation Failure." China: An International Journal 2: 210-234.

Della Porta, Donatella, and Olivier Fillieule. 2004. "Policing Social Protest." In The Blackwell Companion to Social Movements, ed. David A. Snow, Sarah A. Soule, and Hanspeter Kriesi, 217-241. Malden, MA: Blackwell.

Deng, Yanhua, and Kevin J. O'Brien. 2012. "Relational Repression in China: Using Social Ties to Demobilize Protesters." The China Quarterly 215: 533-552.

Earl, Jennifer. 2006. "Introduction: Repression and the Social Control of Protest." Mobilization: An International Quarterly 11: 129-143.

Edin, Maria. 2003. "State Capacity and Local Agent Control in China: CCP Cadre Management from a Township Perspective." The China Quarterly 173: 35-52.

Ferree, Myra Marx. 2004. "Soft Repression: Ridicule, Stigma, and Silencing in Gender-Based Movements." In Authority in Contention, ed. Daniel J. Myers and Daniel M. Cress, 85-102. Bingley, UK: Emerald Group Publishing.

Goldstone, Jack, and Charles Tilly. 2001. "Threat (and Opportunity): Popular Action and State Response in the Dynamics of Contentious Action." In Silence and Voice in the Study of Contentious Politics, ed. R. R. Aminzade et al., 179-194. New York: Cambridge University Press. 
Gu, Guilin. 2002. "Nongmin weihe xin 'fang' bu xin 'fa"" [Why do farmers believe in petititioning not law?]. In Renmin Daibiao Bao [People's representative newspaper]. Online. http://www.wtolaw.gov.cn/display /displayInfo.asp?IID=20021201151247012.

Harff, Barbara. 2003. "No Lessons Learned from the Holocaust? Assessing Risks of Genocide and Political Mass Murder Since 1955." American Political Science Review 97: 57-73.

Hough, Jerry F. 1969. The Soviet Prefects: The Local Party Organs in Industrial Decision-making. Cambridge, MA: Harvard University Press.

Hurst, William, and Kevin O'Brien. 2002. “China's Contentious Pensioners." The China Quarterly 170: 345-360.

Kelliher, Daniel Roy. 1992. Peasant Power in China: The Era of Rural Reform, 1979-1989. New Haven, CT: Yale University Press.

Kerkvliet, Benedict J. 2005. The Power of Everyday Politics: How Vietnamese Peasants Transformed National Policy. Ithaca, NY: Cornell University Press.

Lam, Tao-Chiu, and Hon S. Chan. 1996. "Reforming China's Cadre Management System: Two Views of a Civil Service." Asian Survey 36: $772-781$.

Landry, Pierre, Xiaobo Lü, and Haiyan Duan. 2013. "Fiscal Accountability Under Autocracy." Paper presented at the American Political Science Association Annual Conference, Chicago.

Li, Lianjiang, Mingxing Liu, and Kevin O'Brien. 2012. "Petitioning Beijing: The High Tide of 2003-2006." The China Quarterly 210: 313-334.

Mertha, Andrew. 2008. China's Water Warriors: Citizen Action and Policy Change. Ithaca: Cornell University Press.

Michelson, Ethan. 2007. "Climbing the Dispute Pagoda: Grievances and Appeals to the Official Justice System in Rural China." American Sociological Review 72: 459-485.

Minzner, Carl F. 2006. "Xinfang: An Alternative to Formal Chinese Legal Institutions." Stanford Journal of International Law 42: 103-179.

Nathan, Andrew. 2003. "Authoritarian Resilience." Journal of Democracy 14: 6-17.

O’Brien, Kevin J., and Lianjiang Li. 1995. "The Politics of Lodging Complaints in Rural China." The China Quarterly 143: 756-783.

- 1999. "Selective Policy Implementation in Rural China." Comparative Politics 31, 2: 167-186.

- 2004. "Suing the Local State: Administrative Litigation in Rural China." The China Quarterly 51: 75-96.

- 2006. Rightful Resistance in Rural China. New York: Cambridge University Press.

Oi, Jean. 1999. Rural China Takes Off: Institutional Foundations of Economic Reform. Berkeley: University of California Press.

Perry, Elizabeth. 2003. “"To Rebel Is Justified': Cultural Revolution Influences on Contemporary Chinese Protest." In The Chinese Cultural Rev- 
olution Reconsidered: Beyond Purge and Holocaust, ed. Kam-Yee Law, 262-281. New York: Palgrave Macmillan.

Rueschemeyer, Marilyn. 1991. "Participation and Control in a State Socialist Society: The German Democratic Republic." East Central Europe 18, 1: 23-53.

Schedler, Andreas, and Bert Hoffmann. 2012. "The Dramaturgy of Authoritarian Elite Cohesion." Paper presented at the American Political Science Association Annual Conference, New Orleans.

Scott, James C. 1985. Weapons of the Weak: Everyday Forms of Peasant Resistance. New Haven, CT: Yale University Press.

Shih, Victor, Christopher Adolph, and Mingxing Liu. 2012. "Getting Ahead in the Communist Party: Explaining the Advancement of Central Committee Members in China." American Political Science Review 106: $166-187$.

Sun, Yan. 2008. "Cadre Recruitment and Corruption: What Goes Wrong?" Crime Law Social Change 49: 61-79.

Svolik, Milan W. 2012. The Politics of Authoritarian Rule. New York: Cambridge University Press.

Tarrow, Sidney G. 1994. Power in Movement: Social Movements, Collective Action and Politics. New York: Cambridge University Press.

Thornton, Patricia M. 2002. "Framing Dissent in Contemporary China: Irony, Ambiguity and Metonymy." The China Quarterly 171: 661-681.

Tian, Xianhong. 2010. "Cong weiquan dao mouli: Nongmin shangfang xingwei luoji bianqian de yige jieshi kuangjia" [From rights to interests: A framework to explain logic change in farmers' petitioning]. Kaifang shidai [Open time] 6.

Tong, Caroline Haiyan, Jeffrey Straussman, and Walter D. Broadnax. 1999. "Civil Service Reform in the People's Republic of China: Case Studies of Early Implementation.” Public Administration and Development 19: 193-206.

Xiao, Tangbiao. 2005. "Zhongguo zhengzhi gaige de tizhi nei ziyuan: Dui difang guanyuan zhengzhi taidu de diaocha yu fenxi" [Institutional resources for China's political reform: Investigation and analysis of local officials' political perception]. Dangdai Zhongguo yanjiu [Modern China studies] 3.

Yang, Guobin. 2005. "Emotional Events and the Transformation of Collective Action." In Emotions and Social Movements, ed. H. Flam and D. King, 79-95. London: Routledge.

Ying, Xing. 2007. "'Qi' yu Zhongguo xiangcun jiti yundong de zai shengchan" ["Qi" and the reproduction of rural collective action in China]. Open Times 6: 106-120.

$\mathrm{Yu}$, Jianrong. 2003. "Woguo xianjieduan nongcun quntixing shijian de zhuyao yuanyin" [Main causes of rural mass incident in present day China]. Zhongguo nongcun jingji [Rural economy in China] 6: 75-78.

Zen, Jinsheng. 2007. “Jingti 'jiefang' duse minyi tongdao" [Retrieving petitioners may block the channels for people's voices]. In Renmin Luntan 
[People's forum]. Online. http://politics.people.com.cn/GB/30178/5402 847.html.

Zhang, Taisu. 2009. "Zhongguoren zai xingzheng jiufen zhong weihe pianhao xinfang?" [Why do Chinese prefer petitioning on administrative dispute?]. Shehuixue yanjiu [Sociology studies] 3: 139-162.

Zhao, Dingxin. 1998. "Ecologies of Social Movements: Student Mobilization During the 1989 Prodemocracy Movement in Beijing." American Journal of Sociology 103: 1493-1529.

Zhao, Yunqi. 2007. "Zhongguo dangdai nongmin fudan wenti yanjiu (1949-2006)" [Studies on farmers' burdens in contemporary China]. Zhongguo jingji shi yanjiu [Studies of economic history in China] 3: 97-106.

Zhou, Kate Xiao. 1996. How the Farmers Changed China: Power of the People. Boulder, CO: Westview Press.

Ziegenhagen, E. 1986. The Regulation of Political Conflict. New York: Praeger. 


\section{China's Regional Relations:}

\section{Evolving Foreign} Policy Dynamics

\section{mark Beeson and Fujian li}

CC $\Delta$ insightful analysis.... The authors 1 display a thorough knowledge of the Chinese perspective, including the views of both the party-state leadership and Chinese netizens."-Choice

"An excellent overview of China's foreign relations and the impact of China's rise on the world and East Asia."

\section{-Yong Wang, Peking University}

Has China's much-discussed "charm offensive" come to an end? Are fears about the country's more assertive foreign policies justified? How will a rising China interact with its regional neighbors? Mark Beeson and Fujian Li address these questions by comprehensively exploring the nature, effectiveness, and implications of China's foreign policy strategy in Asia and Australia.

\section{CONTENTS}

- China Changes Everything.

- India, Russia, and Central Asia.

- The Rise of Regions.

- Sino-Australian Relations.

- China Transformed.

- A Regional or a Global Power?

- East Asia or Asia Pacific?

- Southeast Asia.

2014/254 pages • he \$59.95

- Northeast Asia. 